\title{
Editorial: Myelin-Mediated Inhibition of Axonal Regeneration: Past, Present, and Future
}

\author{
Sari Hannila ${ }^{1}$ and Wilfredo Mellado ${ }^{2 *}$ \\ ${ }^{1}$ Department of Human Anatomy and Cell Science, College of Medicine, University of Manitoba, Winnipeg, MB, Canada, \\ ${ }^{2}$ Laboratory for Axonal and RNA Biology, Burke-Cornell Medical Research Institute, White Plains, NY, USA
}

Keywords: myelin inhibitors, myelin associated glycoprotein, Nogo, OMgp, neuronal regeneration

\section{Editorial on the Research Topic}

\section{Myelin-Mediated Inhibition of Axonal Regeneration: Past, Present, and Future}

Impact: what every scientist seeks in their career. It is a sign of widespread influence, a reflection of the field's continued interest, and validation of our ideas. The impact of a scientist's work is often expressed using simple numbers found in citation reports, journal impact factors, and hindices, but perhaps the truest measure is the respect of their peers. By this metric, the impact of Dr. Marie T. Filbin's life and career was profound, as evidenced by the many articles published by friends and colleagues in remembrance of Marie since her passing (Ashe and Roskams, 2014; Maddox, 2014; Melendez-Vasquez, 2014; Roskams et al., 2014; Stephenson, 2014). For those of us who had the privilege of working in her laboratory, our fond personal memories are intertwined with a deep desire to preserve and promote her scientific legacy, and this was the driving force behind this Frontiers Research Topic. There were few things that Marie enjoyed more than talking about science, so we could think of no better way to honor her memory than to invite our colleagues to share perspectives on the current state and future direction of the field she helped create.

The hypothesis that central nervous system (CNS) myelin inhibits axonal regeneration was first proposed in the early 1980s (Berry, 1982), and Marie played a central role in identifying myelinassociated glycoprotein (MAG) as the first myelin-associated inhibitor (McKerracher et al., 1994; Mukhopadhyay et al., 1994). This was soon followed by the discovery of other myelin proteins that inhibit axonal growth, such as Nogo-A (Chen et al., 2000; GrandPré et al., 2000; Prinjha et al., 2000), oligodendrocyte-myelin glycoprotein (Kottis et al., 2002; Wang et al., 2002a), and ephrin-B3 (Benson et al., 2005), as well as the receptors and co-factors that mediate their effects, including Nogo receptor (Fournier et al., 2001; Domeniconi et al., 2002; Oertle et al., 2003), paired immunoglobulin receptor B (Atwal et al., 2008), the p75 neurotrophin receptor (Wang et al., 2002b), and low-density lipoprotein receptor-related protein 1 (Stiles et al., 2013). Since their discovery, these proteins and receptors have been widely investigated as potential targets for promoting axonal regeneration after spinal cord injury.

This e-book begins with several reviews that expand on the theme of myelin and its function in the injured CNS. While myelin-associated inhibitors are typically viewed in a negative light, these proteins do have normal physiologic roles that have been discussed by Baldwin and Giger. The next chapter is a historical and personal overview of the myelin-associated inhibitor field by McKerracher and Rosen. It is followed by a review from Soheila Karimi-Abdolrezaee's lab that describes the pathophysiologic events that affect oligodendrocytes after CNS injury, as well as cellular approaches currently used to promote remyelination (Alizadeh et al.). This topic is examined from a neuronal perspective by Kaplan et al. in their discussion of how neuronintrinsic factors contribute to both axonal regeneration and inhibitory factor neutralization in the extracellular environment (Kaplan et al.), which serves as a fitting counterpart to the review by 
Rao and Pearse that comprehensively describes how specific axon-glia signaling pathways influence both myelination and axonal regeneration.

In 1999, the Filbin lab made another seminal contribution to the axonal regeneration field when they reported that elevation of cyclic AMP (cAMP) in postnatal rat neurons was sufficient to overcome inhibition by MAG and CNS myelin (Cai et al., 1999). They subsequently showed that the increase in cAMP enhanced protein kinase A activity and downstream activation of transcription factors such as cAMP-responsive element binding protein (CREB; Gao et al., 2004). To identify which genes were upregulated in response to cAMP, Jason Carmel performed a microarray analysis of cAMP-treated neurons plated on myelin substrates, and together with Wise Young and Ronald Hart, he describes his findings in this collection of reviews (Carmel et al.). Several genes identified in this screen-arginase I, interleukin 6, secretory leukocyte protease inhibitor, and metallothionein I/IIwere shown to overcome MAG inhibition in their own right, and their effects and mechanisms are discussed by Siddiq and Hannila.

Interestingly, analysis of the promoter regions of some of these genes revealed that they did not contain cAMP response elements, which suggests that other transcription factors are involved in reversing the effects of myelin-associated inhibitors. Using embryonic mouse neurons grown in the presence of MAG, it was recently demonstrated that another transcription factor, activator protein 1 , functions synergistically with CREB to induce arginase I expression (Ma et al., 2014). An earlier study identified several compounds that allowed cerebellar neurons to overcome myelin inhibition, but surprisingly, they did not elevate cAMP (Usher et al., 2010). This led to the hypothesis that non-cAMPregulated genes also play a substantial role in blocking myelinmediated inhibition, and it raises the interesting question of

\section{REFERENCES}

Ashe, J., and Roskams, J. (2014). Marie T. Filbin: in memoriam. Neuron 82, 509-510. doi: 10.1016/j.neuron.2014.04.033

Atwal, J. K., Pinkston-Gosse, J., Syken, J., Stawicki, S., Wu, Y., Shatz, C., et al. (2008). PirB is a functional receptor for myelin inhibitors of axonal regeneration. Science 322, 967-970. doi: 10.1126/science.1161151

Benson, M. D., Romero, M. I., Lush, M. E., Lu, Q. R., Henkemeyer, M., and Parada, L. F. (2005). Ephrin-B3 is a myelin-based inhibitor of neurite outgrowth. Proc. Natl. Acad. Sci. U.S.A. 102, 10694-10699. doi: 10.1073/pnas.0504021102

Berry, M. (1982). Post-injury myelin-breakdown products inhibit axonal growth: an hypothesis to explain the failure of axonal regeneration in the mammalian central nervous system. Bibl. Anat. 23, 1-11.

Cai, D., Shen, Y., De Bellard, M., Tang, S., and Filbin, M. T. (1999). Prior exposure to neurotrophins blocks inhibition of axonal regeneration by MAG and myelin via a cAMP-dependent mechanism. Neuron 22, 89-101. doi: 10.1016/S0896-6273(00)80681-9

Chen, M. S., Huber, A. B., van der Haar, M. E., Frank, M., Schnell, L., Spillmann, A. A., et al. (2000). Nogo-A is a myelin-associated neurite outgrowth inhibitor and an antigen for monoclonal antibody IN-1. Nature 403, 434-439. doi: $10.1038 / 35000219$

Domeniconi, M., Cao, Z., Spencer, T., Sivasankaran, R., Wang, K., Nikulina, E., et al. (2002). Myelin-associated glycoprotein interacts with the Nogo66 receptor to inhibit neurite outgrowth. Neuron 35, 283-290. doi: 10.1016/S0896-6273(02)00770-5 how to identify and manipulate regeneration-associated genes to enhance axonal regeneration, a topic that is discussed by Ma and Willis.

Fittingly, we end with a contribution from Marie's laboratory on the subject that first brought her to prominence: MAG biochemistry and function. As a member of the Siglec family, it is well known that MAG can bind complex gangliosides such as GT1b and GD1a (Kelm et al., 1994; Vinson et al., 2001), but the role of sialic acid-binding in MAG-mediated inhibition of neurite outgrowth remains contentious. Najat Al-Bashir's review presents a new working model describing how sialic acid binding at Arg 118 is required to mediate inhibition by soluble but not membrane-bound forms of MAG (Al-Bashir et al.). While this story would appear to bring Marie's career full circle, it is in fact a reminder of all that remains unknown in this field and the work that still lies ahead. New discoveries regarding the effects of MAG, Nogo, and other myelin-associated inhibitors will undoubtedly provoke debate, and that is something Marie would have welcomed.

She also would have been deeply grateful to all of the distinguished scientists who contributed to this Research Topic, and we extend our deepest thanks to each of them for their time and efforts. We also would like to thank the reviewers for their input and the staff of Frontiers in Molecular Neuroscience for their support and guidance throughout this process, one that has been personally and scientifically rewarding for both of us.

\section{AUTHOR CONTRIBUTIONS}

All authors listed, have made substantial, direct and intellectual contribution to the work, and approved it for publication.
Fournier, A. E., GrandPré, T., and Strittmatter, S. M. (2001). Identification of a receptor mediating Nogo-66 inhibition of axonal regeneration. Nature 409, 341-346. doi: 10.1038/35053072

Gao, Y., Deng, K., Hou, J., Bryson, J. B., Barco, A., Nikulina, E., et al. (2004). Activated CREB is sufficient to overcome inhibitors in myelin and promote spinal axon regeneration in vivo. Neuron 44, 609-621. doi: 10.1016/j.neuron.2004.10.030

GrandPré, T., Nakamura, F., Vartanian, T., and Strittmatter, S. M. (2000). Identification of the Nogo inhibitor of axon regeneration as a Reticulon protein. Nature 403, 439-444. doi: 10.1038/35000226

Kelm, S., Pelz, A., Schauer, R., Filbin, M. T., Tang, S., de Bellard, M. E., et al. (1994). Sialoadhesin, myelin-associated glycoprotein and CD22 define a new family of sialic acid-dependent adhesion molecules of the immunoglobulin superfamily. Curr. Biol. 4, 965-972. doi: 10.1016/S0960-9822(00) 00220-7

Kottis, V., Thibault, P., Mikol, D., Xiao, Z. C., Zhang, R., Dergham, P., et al. (2002). Oligodendrocyte-myelin glycoprotein (OMgp) is an inhibitor of neurite outgrowth. J. Neurochem. 82, 1566-1569. doi: 10.1046/j.1471-4159.2002.01146.x

Ma, T. C., Barco, A., Ratan, R. R., and Willis, D. E. (2014). cAMP-responsive element-binding protein (CREB) and cAMP co-regulate activator protein 1 (AP1)-dependent regeneration-associated gene expression and neurite growth. J. Biol. Chem. 289, 32914-32925. doi: 10.1074/jbc.M114.582460

Maddox, S. (2014). Distinguished Spinal Cord Injury Scientist Dies. Available online at: http://www.spinalcordinjury-paralysis.org/blogs/18/1816 
McKerracher, L., David, S., Jackson, D. L., Kottis, V., Dunn, R. J., and Braun, P. E. (1994). Identification of myelin-associated glycoprotein as a major myelin-derived inhibitor of neurite growth. Neuron 13, 805-811. doi: 10.1016/0896-6273(94)90247-X

Melendez-Vasquez, C. V. (2014). A Tribute to Dr. Marie T. Filbin from One Who Benefited. Available online at: http://www.asneurochem.org/about-the-asn/18-about-the-asn/history/63

Mukhopadhyay, G., Doherty, P., Walsh, F. S., Crocker, P. R., and Filbin, M. T. (1994). A novel role for myelin-associated glycoprotein as an inhibitor of axonal regeneration. Neuron 13, 757-767. doi: 10.1016/0896-6273(94)90042-6

Oertle, T., van der Haar, M. E., Bandtlow, C. E., Robeva, A., Burfeind, P., Buss, A., et al. (2003). Nogo-A inhibits neurite outgrowth and cell spreading with three discrete regions. J. Neurosci. 23, 5393-5406.

Prinjha, R., Moore, S. E., Vinson, M., Blake, S., Morrow, R., Christie, G., et al. (2000). Inhibitor of neurite outgrowth in humans. Nature 403, 383-384. doi: $10.1038 / 35000287$

Roskams, J., Tuszynski, M., and Steward, O. (2014). Marie Filbin 1955-2014. Nat. Neurosci. 17, 331. doi: 10.1038/nn.3665

Stephenson, F. A. (2014). Marie T. Filbin. J. Neurochem. 130, 605-607. doi: $10.1111 /$ jnc.12797

Stiles, T. L., Dickendesher, T. L., Gaultier, A., Fernandez-Castaneda, A., Mantuano, E., Giger, R. J., et al. (2013). LDL receptor-related protein-1 is a sialic-acidindependent receptor for myelin-associated glycoprotein that functions in neurite outgrowth inhibition by MAG and CNS myelin. J. Cell Sci. 126, 209-220. doi: 10.1242/jcs.113191
Usher, L. C., Johnstone, A., Erturk, A., Hu, Y., Strikis, D., Wanner, I. B., et al (2010). A chemical screen identifies novel compounds that overcome glialmediated inhibition of neuronal regeneration. J. Neurosci. 30, 4693-4706. doi: 10.1523/JNEUROSCI.0302-10.2010

Vinson, M., Strijbos, P. J., Rowles, A., Facci, L., Moore, S. E., Simmons, D. L., et al. (2001). Myelin-associated glycoprotein interacts with ganglioside GT1b. A mechanism for neurite outgrowth inhibition. J. Biol. Chem. 276, 20280-20285. doi: 10.1074/jbc.M100345200

Wang, K. C., Kim, J. A., Sivasankaran, R., Segal, R., and He, Z. (2002b). P75 interacts with the Nogo receptor as a co-receptor for Nogo, MAG and OMgp. Nature 420, 74-78. doi: 10.1038/nature01176

Wang, K. C., Koprivica, V., Kim, J. A., Sivasankaran, R., Guo, Y., Neve, R. L., et al. (2002a). Oligodendrocyte-myelin glycoprotein is a Nogo receptor ligand that inhibits neurite outgrowth. Nature 417, 941-944. doi: 10.1038/nature00867

Conflict of Interest Statement: The authors declare that the research was conducted in the absence of any commercial or financial relationships that could be construed as a potential conflict of interest.

Copyright (c) 2017 Hannila and Mellado. This is an open-access article distributed under the terms of the Creative Commons Attribution License (CC BY). The use, distribution or reproduction in other forums is permitted, provided the original author(s) or licensor are credited and that the original publication in this journal is cited, in accordance with accepted academic practice. No use, distribution or reproduction is permitted which does not comply with these terms. 